\title{
The Placement of Lucian's Novel True History in the Genre of Science Fiction
}

\author{
KATELIS VIGLAS
}

\begin{abstract}
Among the works of the ancient Greek satirist Lucian of Samosata, well-known for his scathing and obscene irony, there is the novel True History. In this work Lucian, being in an intense satirical mood, intended to undermine the values of the classical world. Through a continuous parade of wonderful events, beings and situations as a substitute for the realistic approach to reality, he parodies the scientific knowledge, creating a literary model for the subsequent writers. Without doubt, nowadays, Lucian's large influence on the history of literature has been highlighted. What is missing is pointing out the specific characteristics that would lead to the placement of True History at the starting point of Science Fiction. We are going to highlight two of these features: first, the operation of "cognitive estrangement", which aims at providing the reader with the perception of the difference between the convention and the truth, and second, the use of strange innovations ("novum") that verify the value of Lucian's work by connecting it to historicity.
\end{abstract}

Keywords: Lucian of Samosata; True History; satire; estrangement; "novum"; Science Fiction

\section{Introduction}

Initially, we are going to present a biography of Lucian in relation to the spirit of his era and some judgments on his work. Furthermore, we will proceed to a brief reference to the influences exerted by his novel True History on the history of literature, especially on the genre of Science Fiction. In general, the search for the roots of the genre of Science Fiction in the literary canon could take us back to the beginning of the first written records of ancient civilization. Thus, the Epic of Gilgamesh, Plato's The Republic, Lucian's satires, the Utopia of Thomas More, and Jonathan Swift's Gulliver's Travels, are sometimes included in genealogies of Science Fiction (Scholes-Rabkin 1977: 6-7). Lucian's description of voyages to the Moon and Sun provided inspiration to many proto-Science Fiction writers, all of whom recounted similar fantastic voyages. For those Science Fiction writers, Lucian may be considered a 
spiritual forefather, but not in a generative sense lineal (Disch 2000: 32-33). The decrease of the influence of Lucian's work has been caused by religious or moral restrictions since it was considered blasphemous for long historical periods.

The novel True History is characterized by para-literary elements, surpassing the conventional and traditional forms. Also, some brief references to the novel's narrative are necessary in order to understand its overview and to realize its quality. But the challenge is to add two main reasons which explain the historically known influences of Lucian's work on classical literature and which arise from the contemporary criticism, as parts of a fundamental definition of Science Fiction. These two additional points are, first, the concept of "cognitive estrangement", and second, the category of

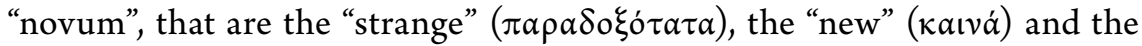
"bizarre" (å $\lambda \lambda$ óko $\tau \alpha)$ elements contained in the novel under consideration.

\section{Lucian's life and judgments on his work}

Lucian lived and worked in the Roman Empire at the time of the Five Good Emperors (96-180 AD). During the reign of Trajan, from 98 to 117 AD, the Roman Empire saw the largest expansion of territory. The Hellenization was very extensive and many oriental ideas flooded Rome. Lucian was born between 115 and $125 \mathrm{AD}$, in the ancient city of Samosata near Euphrates, the former capital of the Kingdom of Commagene. There are many scattered references to his life in his works, but most of them are not reliable. $\mathrm{He}$ received his education at an advanced age in Ionia and he practiced rhetoric, traveling in mainland Greece, Italy and Gaul, before becoming a satirist. While still alive, he won many riches and fame, especially thanks to his entertaining and impromptu speeches. His contemporary, the physician Galen, mentioned that Lucian mimicked Heraclitus, creating some false writings of the Ephesian pre-Socratic philosopher. In 163, he came in contact with the co-emperor of Marcus Aurelius, Lucius Aurelius Verus. He died in Egypt after 180 AD (Gagarin 2009: 1596-1599).

Lucian's work expressed the spirit of his era and the religious syncretism. He belongs to the tradition of Menippean Satire, as he developed alternative forms of expression in order to undermine traditional literature (Freundenbuck 2005: 109-112; Hutcheon 1994: 9; Muecke 1986: 7). He has not had a good reputation since antiquity. In the Byzantine encyclopedic dictionary of the $10^{\text {th }}$ century named Souda, it is noted that he was considered a blasphemer, slanderer and atheist. In 1559, some of his dialogues were included in the papal 
"List of Prohibited Books" (Index Librorum Prohibitorum). In Europe, after the Reformation, both Protestants and Catholics strongly criticized his work. However, an upsurge of interest in the latter occurred under Postmodernism (Roberts 2006: 21-23). ${ }^{1}$ The Russian theorist Mikhail Bakhtin connected it with popular "laughter" ( $\gamma \varepsilon \dot{\varepsilon} \lambda \omega \varsigma)$ since from ancient times they placed it in the genre of "spoudogeloion" ( $\sigma \pi \circ v \delta \circ \gamma \varepsilon \dot{\varepsilon}$ oเov, a compound of "serious" ( $\sigma \pi \circ \delta \delta \alpha$ ĩv) and "laughable" ( $\gamma \varepsilon \lambda \circ$ õov)) (2008). Bakhtin placed the origins of such a literary genre in the reversal of the hierarchies during the popular carnival. In this regard, Lucian's work combines the sublime with the ridiculous, reflecting a "carnival sense of the world" (Bakhtin 1999: 107). About eighty-six works have been attributed to Lucian - although probably he is not the author of all of them - which can be divided into categories, while some of them are of little interest. In his works, essays, biographies, dialogues, poetic and rhetorical texts, and some novels are included. Among the latter, True History and Icaromenippus should be considered as the first texts of Science Fiction (Clute-Nicholls 1995).

Among others critics, James Gunn agrees that the first extended narrative that has enough of the qualities of Science Fiction is the True History by Lucian. Although Lucian's sailing ship is no spaceship, and his adventurers have no intention of going to the Moon, the author's purpose is not to make such a journey credible or to speculate about what we might find if we could really make the journey. Lucian was writing satire, but his sailing ship is not that much different from Edgar Allan Poe's balloon in his short story The Unparalleled Adventure of One Hans Pfaall (1835) or Jules Verne's cannon shell in the novel From the Earth to the Moon (1865), and the story probably was read largely for its adventure and its inventiveness. Finally, Gunn holds the view that True History inspired a long chain of literary descendants, including Johannes Kepler, Francis Godwin, Cyrano de Bergerac, Jonathan Swift, Voltaire, Edgar Allan Poe, et al. (Gunn 2002: 1-2).

Certainly, there are many theories of literature with which Lucian's work could be discussed and interpreted in various ways, as are Gunn's views from within the so called "Science Fiction ghetto". Moreover, Gunn gives the following definition of the genre of Science Fiction: "a fantastic event of development considered rationally", although he notes that it lacks precision. Also, the same critic considers Science Fiction as the branch of literature that deals with the effects of change on people as it can be projected into the past, the future, or to distant places. He points out that Science Fiction often concerns itself with scientific or technological change, and it usually involves matters the

1 Lucian was named H. L. Mencken of Greek Literature (Hendrick-Shea 2005: XVI). 
importance of which is greater than the individual or the community. For this critic, Science Fiction is a literature of (1) ideas; (2) change; (3) anticipation; (4) the human species; (5) discontinuity, in contrast to literary fiction which is the literature of continuity (Gunn-Candelaria 2005: 5-12).

The "cognitive estrangement" and the "novum" according to Darko Suvin

However, in the current study, Darko Suvin's thinking is chosen to prove Lucian's primary position in the Science Fiction canon, because of his modern and clarified perception about the nature of this genre. The terms Suvin coined are clear and straightforward as hermeneutical tools. His thought is considered here as an adequate, historically defined perspective of the past, not necessarily timeless or universally accepted. The present approach cannot be in any way considered an anachronism.

Suvin in his book Metamorphoses of Science Fiction (1979) initiated the term literature of "cognitive estrangement". The concept of estrangement played an important role in the literary criticism of the $20^{\text {th }}$ century. This concept was used extensively by the Russian Formalists, Surrealists and Postmodernists. Major theorists of this concept were Viktor Shklovsky and Berthold Brecht, before it was used by Suvin. ${ }^{2}$ According to the latter, in terms of Science Fiction (ibid. 4), the concept of "science" corresponds to that of "knowledge" and the concept of "fiction" to that of "estrangement", but they are not identical (ibid. 13). By the concept of estrangement, Suvin characterizes the relationship between the narrative and the empirical world, in the sense that the estranged world of narrative contains some wonderful items that do not seem to be part of our reality (Spiegel 2008: 371; Suvin 1988: 37). According to Suvin, whenever a wondrous item is inserted into an imaginative world, a break happens between the two reality systems, producing a sense of estrangement (ibid. 375). He further argued that this literary genre began with Lucian and the Greeks, before the name and the awareness of it existed. Although the majority of critics accept that Suvin's coherent tradition exists, he did not provide extensive accounts from the sources in order to support his position (James 2000: 29).

Another related element of "cognitive estrangement" in Science Fiction is the strange inventions, that Suvin called "novum" (1979: 63-84). The concept

2 The corresponding word in German is Verfremdung and it is used for the concept of "ostranenie" (Spiegel 2008: 369). 
VIGLAS

of "novum" according to Suvin implies an entire transformation of the world of the literary work, or at least of the main points on which it can rely. Therefore, if the essential trend of Science Fiction is to express the readers of its time, at the same time includes an opening towards the Unknown or the Other, that is the "novum". According to Suvin the "novum" is an intermediate category stemming from a rare bridging of the literary with the non-literary, the narrative with the empirical, and the morphological with the ideological field, integrating the literary work in its undeniable historicity. In this way, Science Fiction can be verified as knowledge (ibid. 68).

\section{Comments on the novel True History}

In the work True History, Lucian tried to ridicule the idea that the literary, historical and philosophical tradition before him reveals the truth (Sidwell 2004: 307-308). Lucian was humorously imitating the Greek romance novels of his time and would have snickered to think of someone taking the idea of flying to the Moon as anything but absurdity. In much the same way, the subsequent Science Fiction "satirists and farceurs have taken their impetus from pulp Science Fiction, using its stock figures - astronauts and aliens - for their own japes and gambols" (Disch 2000: 32-33).

As can be seen from the description of the plot and the synopsis of his work, there are three main phases of the journey of the narrator: the ascent to the Moon, the fall into the sea along with entering the belly of a whale, and the long stay on the Island of the Blest.

At the beginning of the novel, Lucian says that the satirical stories are for listeners what relaxation is for people interested in sports (Harmon 1961: 248). He says in the first person:

"Not having had any adventures of significance, I took to lying. But my lying is far more honest than theirs, for though I tell the truth in nothing else, I shall at least be truthful in saying that I am a liar."

This is a mocking reference to the famous words of Socrates: "I know one thing that I know nothing." ${ }^{3}$ If, according to Socrates, what matters are the ignorance and the certainty in the name of finding an intelligible reality, Lucian disbelieves the possibility of the acquisition of certainties based on metaphysics and ontology. The condition of "cognitive estrangement" applies in this case since the possession of truth is undermined.

3 Reported by Plato in the first part of Apology (Colebrook 2004: 6-7; Nehamas 1998: 46). 
Lucian, as Thomas More in his Utopia will do later, provided numerous ambiguities, contradictions and paradoxes which highlight a subversive irony, undermining the credibility of what he said (Yoran 2010: 159-160). ${ }^{4}$ Even Rudolf Erich Raspe's work entitled The Surprising Adventures of Baron Munchausen, in which he describes many strange and surprising events, bears the unmistakable influence of Lucian. ${ }^{5}$

Beginning of the voyage, discovery of new worlds and the ascent to the Moon

Lucian presents as poetic license himself involved in a voyage that begins with fifty others in a ship with supplies. They are directed west to the Pillars of Hercules to discover the end of the Ocean and the people who live on the other side (Georgiadou-Larmour 1998: 8). This is therefore a trip for reasons of curiosity and search of the external reality. As will later appear in the novel Candide by Voltaire, where even in the legendary Eldorado of Latin America (2006: 39) the allegorical and satirical reference to philosophical concepts does not cease, Lucian combines adventure with cognitive search. In their course, they find an island and twenty of them explore the area. On their way, they encounter a river where plenty of wine flows. In fact, upon eating the fish, they become drunk. Lucian, intending to mock the legends of fertility of land and vegetation, writes that they see some women who look like vines, like the nymph Daphne. But when they try to kiss them they are drunk again, and when some embrace them, they also become plants. ${ }^{6}$ On another island they come into contact with the Vulture Dragons and they will meet other hybrids. Lucian' hybridization is analogous to the attitude of Jonathan Swift in Gulliver's Travels (Franklin 2009: 91). In the latter the protagonist travels to the land of the horses Houyhnhnms, who are the rulers, and where the deformed humanoids called Yahoos have the role of slaves (Swift 2005: 207).

4 In his era, More was best known as a translator of the works of Lucian, rather than for his work Utopia (Branhan 1985: 23). In More's Utopia, the strangeness and contrast as satirical means exist from the beginning, e.g. the traveler's name is Hythloday ("hythlos" in ancient Greek means "nonsense"). Moreover, More's work sometimes is called "Lucianic", because of both its serious and comic character (Davis 2010: 32).

5 The influence is so extensive, that an older commentator of the third edition of Raspe's work entitled his critic in The Critical Review: or, Annals of Literature as "Lucian revived" (1876: 79).

6 Here we have to do with the "doubts whether an apparently animate being is really alive; or conversely, whether a lifeless object might not be in fact animate" (Freud 2003: 135). 
VIGLAS

Then, Lucian and his companions ascend into space with their ship through a tornado. The author uses an inverse way of approach than what was known in his time in the Hermetic Texts, the Chaldean Oracles, the Gnostic Gospels (Couliano 1984), and the texts that describe the Christian experience of ecstasy, which will often recur in the mystic literature of the Middle Ages. Indeed, this part of Lucian's novel exercised a decisive influence during the late Middle Ages over the Divine Comedy (1321) of Dante Alighieri, in which the poet through the help of the ghost of Beatrice makes a trip to the astral space. On the Moon, Dante encounters not real beings, but those who were not entirely faithful to the religion (Canto III, 1.30). Even Swift in Gulliver's Travels narrated a trip to the flying island Laputa (Swift 2005: 144; Lacaze 2002: 34). Also, in the story Micromégas, Voltaire described a journey into space, although far beyond the solar system of the Earth, to the planets of the Sirius system. Lucian's whole arsenal of bizarre situations and beings, and a tendency towards demystification, are equivalent to a value system in which vitality is equated with freedom (Suvin 1979: 98). Lucian refers, then, to the rise into the celestial spheres, not through a "spiritual vehicle", which Plato had already presented in the myth of the Republic (Res Publica 616c 3; Timaeus 4le1-2; Numenius 1973: fr. 18), ${ }^{7}$ but literally by a material medium.

It is then that Lucian places the action on the Moon, initiating a "Selenographic Tradition" (Suvin 2011: 38), which continued after the Renaissance. In the Italian epic Orlando Furioso by Ludovico Ariosto, the poet sends Duke Astolfo on a hippogriff to the Moon, to meet a dreamy and heavenly environment, which he viewed from the Earth (Ariosto 2009: 604). Also, in Cyrano de Bergerac's Comical History of the States and Empires of the Moon (1657), the hero travels to the Moon to meet biblical and mythological figures, with which he converses on philosophical issues. Similarly, Edgar Alan Poe, ${ }^{8}$ Jules Verne, and Herbert George Wells in his The First Men in the Moon (1901) successfully continued the tradition started by Lucian.

The meeting between the Greeks and the strange entities takes place suddenly. The king of the inhabitants of the Moon, Endymion, battles with Phaethon and the inhabitants of the sun. The war began when the subjects of

This image is probably the impact of the old Egyptian doctrine of the "boat of the soul" (Plotinus 2004: 404).

8 Modern research has shown that the texts published in 1835 in the newspaper The New York Sun about the alleged discovery of life and culture on the Moon, which were characterized as “The Great Moon Hoax", were inspired by True History, and Poe's short story The Unparalleled Adventure of One Hans Pfaall published in the same journal in 1844 (Hilton 2005: 1-20). 
Endymion started to conquer the morning star, Lucifer, in order to establish a colony. Lucian gives to the concept of otherness ${ }^{9}$ forms belonging to the aesthetic category of the grotesque. For example, he writes that Phaethon tried to prevent the inhabitants of the Moon with the help of Ant Dragons. The description of the troops is full of weird and funny beings. The weapons resemble missiles filled with mallow poison. ${ }^{10}$ The exploratory nature of Lucian's voyage and his companions is connected with conquering action. The first victory belongs to Phaethon. After the initial victory of the inhabitants of the Moon, their opponents return, overturning the result. Eventually, the two rival sides capitulate. The specific nature of extraterrestrials, the various races and the wars between them refer to similar situations and phenomena of the socio-political space of the ancient times. The Greco-Roman culture had already integrated many of the foreign societies (Georgiadou-Larmour 1998: 47; Fredericks 1976: 54). In this respect, True History is a precursive reference to the "colonial era" (Grewell 2001: 31).

Lucian describes various phenomena encountered on the Moon, as the "belly of the leg" ( $\gamma \alpha \sigma \tau \rho \circ \kappa \nu \eta i^{\prime} \alpha$, the leg performs the action of a belly) and the people who are called Arboreals $(\Delta \varepsilon v \delta \rho i \tau \varepsilon \varsigma)$. Additionally, the gastronomic habits of the ancient Greeks and Romans are included in the bizarre things, for which there are references to the culinary texts of the period (Giacosa 1992: 13; Olson-Sens 2000: 231). The people on the Moon have clothes of glass, soft for the rich or woven of bronze for the poor. The social stratification of the Earth is reflected in the world of space, without changing the symbolism of the elements since in the Roman era the bronze objects were thought to be inferior to those of glass. The "soft glass" as fabric is reminiscent of the plastic material of the $20^{\text {th }}$ century. These strange situations and objects seem to confirm the theory of Lucian's "carnivalism”. At the place called Lamp City, writes Lucian, between the Pleiades and the Hyades, their ruler stays awake all night and calls each of the lamps by name, otherwise their light dies. The mythical scheme of the voyage is based on the switch life/death, darkness/light, closing/opening. The live lamps foreshadow the development of artificial intelligence and the robotics of our time.

\footnotetext{
9 The Platonic opposition between the category of sameness and the category of otherness is widely known (Timaeus 35a3, sq. Theaetetus 185c9, Sophist 254e3, 255b3, 256d12-e1).

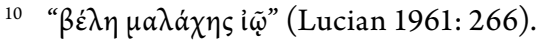


VIGLAS

\section{Return to Earth and the entrance to the whale}

Later, the Greeks reach the sea and enter the belly of a whale, where they find some strange things and people. Lucian's narrative incorporates and parodies many elements of the allegorical interpretation of the Odyssey since for Porphyry ( $3^{\text {rd }}$ century AD) the latter symbolizes the cave that is the material world (Lamberton 1983: 40). A war follows, in which the Greeks win. However, the fights continued with "men sailing on enormous islands as though on triremes". ${ }^{11}$ Even herds of dolphins as assistants and anchors made of glass make their appearance. Eventually, after a forest fire in the whale, they leave, when the whale opens for the second time her mouth, on the fifth day of the ninth month (Lucian 1961: 296). The precise measurement of time in which the imaginary events are recorded, has as a reference point that Suvin called "zero world" (Suvin 1979: 71), i.e. Lucian's home (Whitmarsh 2008: 153-154). ${ }^{12}$ The measurement of time, which is based on the diary of Lucian's homeland, accentuates the estrangement, highlighting the otherness and the unthinkable of the imaginary worlds, which form a contrast to the unquestionable dominance of the Greco-Roman culture.

Certainly, François Rabelais's satirical story entitled The Life of Gargantua and of Pantagruel was influenced by Lucian's work, particularly as regards the idea of "gigantism" (Auerbach 2003: 267-9). In the Second Book of Rabelais's work, the author says that Pantagruel during a heavy rain covered a whole army with his tongue. Then, the description of the narrator's ("Alcofribas Nasier", an anagram of François Rabelais) journey in Pantagruel's mouth follows. When Alcofribas enters the gap of the open jaws, he discovers a completely unknown world: square plains, forests, fortified cities, and more than twenty-five kingdoms. The residents living in Pantagruel's mouth are convinced that their world is more ancient than Earth (Dentith 2005: 243; Bakhtin 1984: 337).

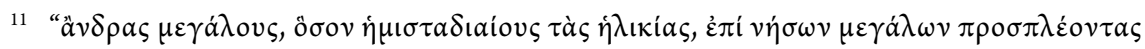

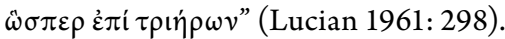

12 The function of "estrangement" must be distinguished from the situation in a strange environment. An adult in a wholly strange environment may be at home and within himself. He may depend more on himself, the less a strange environment welcomes him. But this situation should not be connected with the estrangement or the alienation (Bloch-Halley-Suvin 1970: 120). 


\section{Transition to the Island of the Blest and the place of the ungodly}

After the appearance in the plot of a frozen surface, the use of sleds, the breaking of the ice, and the island of Cork, the action moves to the Island of the Blest. The Island of the Blest, according to Lucian, has a light like the gray morning toward dawn, when the sun has not yet risen, and its ruler is called Rhadamanthus. The arrival at the Island of the Blest can be viewed as a culmination of the voyage of quest. Lucian recounts that he met a city all of gold and the wall around it all of emerald, gates of single plants of cinnamon, a ground within the walls of ivory, temples built of beryl, altars of amethyst, a river of the finest myrrh, large houses of glass as baths, and cloths of delicate purple spider-webs. The residents of this legendary country do not have bodies, although they are substantial and they move and think and speak: they are like upright shadows.

Finally, in the Elysian Fields outside the city surrounded by dense trees of all sorts, a banquet takes place. After a period of six months, in the middle of the seventh month, the travellers are faced with another incident, when Helen tries to escape with one of Lucian's companions. But the fugitives are caught and are punished. Then they sent off to the place of the ungodly. At that point, Lucian describes a hell, with gloomy and misty air, groans of people, the absence of trees, cliffs, thorns and other ills. Then he presents the Island of Dreams, which had gates of ivory. In the end, after battling to a location with huge pelican eggs, bigger than a jar of Chian wine, the story comes to an end, with the appearance of a large, "awkward and terrible ocean chasm", ${ }^{13}$ which has a gulf about a hundred and fifteen miles deep and a bridge constructed of water.

What is the reason why Lucian leaves in the third and final part of his novel the transition to the Island of the Blest and especially to the place of the ungodly, since the descriptions of these places cannot actually be completely enjoyable? The answer is that probably he tries to keep his irony until the end. The irony culminates when Lucian writes that in the place of the ungodly those are more penalized who in their previous life said or wrote the biggest lies. This comment is not just a joke. It is the culmination of the "cognitive estrangement" towards the mystery of death. If death is the absolute otherness, to deal with it with irony, makes it really stranger to life, which ultimately triumphs.

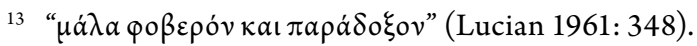




\section{Conclusion}

In conclusion, we could say that in Lucian's novel the scientific knowledge in the fields of geography, astronomy, zoology, and anthropology runs through the narrative since the reader learns constantly about new and different islands, rivers, plants, birds, fish, celestial bodies, hybrids, strange objects, etc. (Georgiadou-Larmour 1998: 45-46). But Lucian presents the scientific erudition as a falsification of true knowledge by his imaginative and utopian constructions. It could be argued that the author's utopian thinking is an expression of the Greek socio-political life (Suvin 1979: 61). ${ }^{14}$ The spirit of utopia, due to Lucian's shocking scenes, is not only a distant mirror of a familiar reality, but an attempt of a creative approach to it (Bloch-Anne Halley-Suvin 1970: 125; Suvin 1979: 10). True History was aimed only partly against the culture within which it was produced since the desire of representation from which the novel proceeded surpassed morphologically this culture. The "Selenographic Tradition" that began with Lucian's work is not therefore related only to the future history of the Moon, but to human history itself (Suvin 2011: 40).

Lucian's work is partially a pastiche, but as a whole it is original and inventive (hence the "novum"). There is a difference between "pastiche" and "parody": the former celebrates, rather than mocks, the work it imitates; the latter aims at imitating, making fun of, or commenting on an original work, by means of satiric or ironic imitation. Lucian's True History rather shares the features of pastiche and parody, as it does not merely imitate but also transfigures its models, exacerbating the caricature aspects of these models. In the case of True History, the combination of intertextuality (pastiche/ parody) with the genre of Science Fiction which belongs to popular literature succeeded, because of the author's literary skills.

The traditional definition of irony as antiphrasis, or saying the opposite of what one means, is not Lucian's primary aim. Instead, his irony is more a "semantically complex process of relating, differentiating, and combining said and unsaid meanings - and doing so with an evaluative edge" (Hutcheon 1994: 89). Lucian's work is an imitation of his forerunners, used as an ironic means of subversion and it tests the limits of ancient civilization. However, although Lucian's irony relies on knowledge shared within the "discursive community" of his place and time, in addition, it can be transmitted to the future generations due to its anticipation of future events.

14 What Bloch has done for the theory of utopia Suvin has arguably done for Science Fiction (Parrinder 2000: 11). 
The Placement of Lucian's Novel True History in the Genre of Science Fiction

The novel True History causes at the same time a sense of comedy and a sense of seriousness, hiding disguised meanings behind its outlandish stories, in order to condemn ironically human weakness. The influence this novel had on important works of world literature, which can be considered as precursors of the Science Fiction of the $20^{\text {th }}$ century, makes it clear why it is usually considered to belong to this genre. Moreover, in the novel two decisive characteristics are included, that lead to the same conclusion. The one is that the empirical and conventional situation of the reader is estranged and the other is that novel's strange findings ("novum") refer to an alternate reality (Booth 1975: ix), which is verified cognitively. Due to the existence of these two features, True History should not be classified as mythology, religion or imaginative and supernatural literature, but the beginnings of Western Science Fiction.

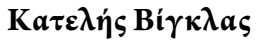 \\ kvigklas@gmail.com

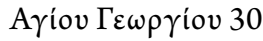 \\ GR-374 00

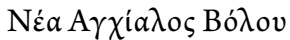 \\ $\mathrm{E} \Lambda \Lambda \mathrm{A} \Delta \mathrm{A} / \mathrm{GREECE}$
}

\title{
Works cited
}

Ariosto, L. 2009. Orlando Furioso. A New Verse Translation [tr. by D. R. Slavitt]. London - Massachusetts - Cambridge: Harvard University Press.

Auerbach, E. 2003. Mimesis. The Representation of Reality in Western Literature [tr. by W. R. Trask]. Princeton: Princeton University Press.

Bakhtin, M. 1984. Rabelais and His World [tr. by Hélène Iswolsky]. Bloomington: Indiana University Press.

Bakhtin, M. 1999 [1985]. Problems of Dostoevsky's Poetics [tr. by Caryl Emerson]. Minneapolis - London: University of Minnesota Press.

Bakhtin, M. 2008 [1981]. Four Essays [tr. by Caryl Emerson and Michael Holquist]. Austin: University of Texas Press.

Bloch, E., Halley, A., Suvin, D. 1970. 'Entfremdung, Verfremdung': Alienation, Estrangement. - The Drama Review: TDR, 15 (1), 120-125.

Booth, W.C. 1975. A Rhetoric of Irony. Chicago - London: The University of Chicago Press.

Branhan, B. 1985. Utopian Laughter: Lucian and Thomas More. - Moreana, 86, 2343.

Brant, J.-A. A., Hedrick, C.W., Shea, C., eds., 2005. Ancient Fiction. The Matrix of Early Christian and Jewish Narrative. Atlanta: Society of Biblical Literature. 
VIGLAS

Colebrook, C. 2004. Irony the New Critical Idiom. London - New York: Routledge.

Couliano, I.P. 1984. Expériences de l'extase: Extase, ascension et récit visionnaire de l'hellénisme au Moyen Age. Paris: Payot.

Davis, J. C. 2010. Thomas More's Utopia: sources, legacy, and interpretation. G. Clays, ed., The Cambridge Companion to Utopian Literature, Cambridge: Cambridge University Press, 28-50.

Dentith, S. 2005. Bakhtinian Thought. An Introductory Reader. London - New York: Routledge.

Disch, T. M. 2000. The Dreams Our Stuff Is Made Of: How Science Fiction Conquered the World. New York: Touchstone.

Franklin, M. J. 2009. Lemuel Self-Translated; Or, Being an Ass in Houyhnhmland. H. Bloom, ed., Jonathan Swift's Gulliver's Travels. New York: Infobase publishing, 75-99.

Fredericks, S. C. 1976. Lucian's True History as SF. - Science Fiction Studies 3 (1), 4960.

Freud, S. 2003. The Uncanny [tr. by David McLintock]. London: Penguin.

Freundenbuck, K., ed. 2005. The Cambridge Companion to Roman Satire. Cambridge: Cambridge University Press.

Gagarin, M., ed. 2009. The Oxford Encyclopedia of Ancient Greece and Rome. Oxford: Oxford University Press.

Georgiadou, A., Larmour, D. H. J. 1998. Lucian's Science Fiction Novel True Histories. Leiden: Brill.

Giacosa, I. G. 1992. A Taste of Ancient Rome. Chicago: University of Chicago Press.

Grewell, G. 2001. Colonizing the Universe: Science Fiction Then, Now, and in the (Imagined) future. - Rocky Mountain Review of Language and Literature, 55 (2), 25-47.

Gunn, J. 2002. The Road to Science Fiction \# 1: From Gilgamesh to Wells. Lanham, Maryland: Scarecrow Press.

Gunn, J., Candelaria M., eds. 2005. Speculation on Speculation. Theories of Science Fiction. Lanham, Maryland - Toronto - Oxford: The Scarecrow Press.

Hilton, J. L. 2005. Lucian and the Great Moon Hoax of 1835. - Acroterion, 50, 1-20, http://akroterion.journals.ac.za/pub/article/view/78/91 (21.12.2014).

Hutcheon, L 1994. Irony's Edge. The Theory and Politics of Irony. London-New York: Routledge.

James, E. 2000. Before the Novum: The Prehistory of Science Fiction Criticism. P. Parrinder, ed. Learning from Other Worlds. Estrangement, Cognition and the Politics of Science Fiction and Utopia. Liverpool: Liverpool University Press, 19-35.

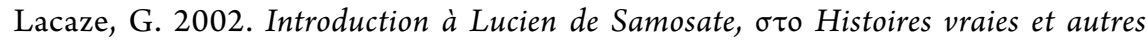
œuvres. Paris: Livre de Poche.

Lucian. 1961. Vol. 1 [tr. by H. M. Harmon]. London - Cambridge: Cambridge University Press.

Lucian. 2004. Chattering Courtesans and other sardonic sketches [tr., ed. and introd. by Keith Sidwell]. London: Penguin Books.

Muecke, D. C. 1986. Irony and the Ironic. London - New York: Methuen. 
The Placement of Lucian's Novel True History in the Genre of Science Fiction

Nehamas, A. 1998. The Art of Living. Socratic Reflections from Plato to Foucault. Berkley - Los Angeles - Oxford: University of California Press.

Numénius. 1973. Fragments. Ed. par E. des Places. Paris : Les Belles Lettres.

Olson, S. D., Sens, A. 2000. Archestratos of Gela: Greek Culture and Cuisine in the Fourth Century BCE. Oxford: Oxford University Press.

Plato. 1902. Res Publica. Ed. by J. Burnet. Oxonii: Clarendoniano.

Plotinus. 2004. Third Ennead. Ed. by P. Kalligas. Athens: Centre for the Research of Greek and Latin Literature.

Poe, E. A. 2002. Complete Tales and Poems. New York: Castle Books.

Roberts, A. 2006. The History of Science Fiction. New York: Palgrave Macmillan.

Scholes R., Rabkin, E. S. 1977. Science Fiction: History, Science, Vision. Oxford: Oxford University Press.

Spiegel, S. 2008. Things Made Strange: On the Concept of "Estrangement" in Science Fiction Theory. - Science Fiction Studies, 35 (3), 369-385.

Suvin, D. 1979. Metamorphoses of Science Fiction: On the Poetics and History of a Literary Genre. New Haven: Yale University Press.

Suvin, D. 1988. Positions and Suppositions in Science Fiction. London: Macmillan.

Suvin, D. 2011. A Life in Letters. Vashon Island, Washington, Paradoxa.

Swift, J. 2005. Gulliver's Travels. Oxford: Oxford University Press.

The Critical Review: or, Annals of Literature. 1876. 62. London: A. Hamilton.

Voltaire. 2006. Candide and Other Stories [tr. by Robert Pearson]. Oxford: Oxford University Press.

Whitmarsh, T. 2008. The Cambridge Companion to the Greek and Roman Novel. Cambridge: Cambridge University Press.

Yoran, Y. 2010. Between Utopia and Dystopia. Erasmus, Thomas More, and the Humanist Republic of Letters. Lanham - Boulder - New York - Toronto - Plymouth: Rowman and Littlefield Publishers. 